\section{Michael Treweeke MBE}

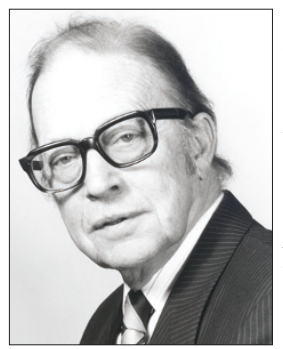

On 28 October 2004, a few days after his 83rd birthday, Michael Treweeke died suddenly but peacefully at his home in Witney, Oxfordshire, where he had lived for 50 years to the month. He came from a family of Cornish farmers who moved to a farm near Chipping Norton a few years before his birth.

Farming was not for Michael however and after leaving school he joined the staff of Barclays Bank. Soon after the outbreak of war he joined the Royal Air Force but within a few months, when on embarkation leave, he contracted measles which resulted in severe complications. He spent five months in the RAF Hospital at Yatesbury during which time he was partially sighted for many weeks and completely blind for a while. Subsequently he was invalided out of the Service and after a complete recovery he rejoined Barclays. After the war he was able to obtain a Government FETS Grant (for ex-servicemen) and so follow the profession in which he was really interested. Married by this time he and his wife Betty moved to Bristol where he qualified as a dentist in 1953.

After a year's assistantship Michael started his own practice in Witney and many years later in Burford. From the outset he was totally committed to his profession. He became deeply involved with BDA and LDC affairs and was soon recognised as an outstanding member. His subsequent appointments and offices make a very long list; suffice it to say that he was held in very high regard by his fellows. Nationally, his worth was recognised by his appointment to the Dental Advisory Committee of the DHSS and the Sunningdale Conference on Dental Timings. For his services to dentistry he was awarded an MBE in 1985.

\section{Norman Duthie}

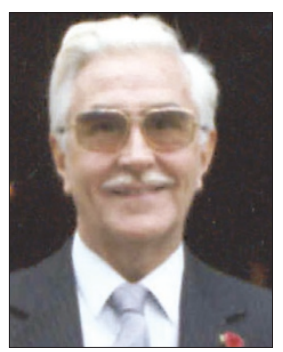

Norman Duthie died on 29 October 2004 in Santa Ponsa, Majorca, aged 77, following a sudden and fatal aortic aneurysm.

A fine black and white photograph of Norman Duthie is displayed in the postgraduate centre in Aberdeen. It is a modest tribute for his distinguished contribution to the development of postgraduate and vocational training in Aberdeen. In the 1970s dental consultants Peter Clarke and Neil Kerr laid the early foundations for a Section 63 postgraduate programme in Aberdeen. Norman, as the first GDP appointed to the post of regional postgraduate adviser, built steadily on these foundations to establish a tradition of high quality courses within a dedicated clinical skills classroom. All this he achieved many years before a national centrally funded body would direct and plan dental postgraduate education in Scotland. In the present seminar rooms new graduates are introduced to the concepts of lifelong learning, critical thinking, good interpersonal skills and the value of presentation and teaching skills as key attributes for the GDP of the future. A man ahead of his time, Norman had these attributes in spades, combined with a caring and generous nature and a tireless dedication to serve the profession he loved.

Norman belonged to Aberdeen and after graduation, this is where he centred his professional life, establishing the King Street practice in 1954 and becoming principal to a succession of young associates. So many of these associates have made contact with Audrey, who worked alongside Norman as the practice manager, recalling with

\section{As well as being a well-loved GDP Michael was a most devoted family man.}

Parallel to this he became learned in dental law. Having been a Hospital Grade Practitioner at Bristol, one day a week for many years, he accepted an appointment there as part-time lecturer in Dental Jurisprudence. This led to membership of the dental advisory board of the MDU, and later as a part-time member of the dental secretariat of the Medical Protection Society.

As well as being a well-loved GDP Michael was a most devoted family man with a daughter, son and four grandchildren. His interests included sailing, DIY, reading, amateur dramatics (in earlier years), active membership of the local Rotary and Probus clubs, and travel. In his retirement he also worked diligently for several charities, especially the RNLI for which he raised thousands of pounds in a variety of ways. Perhaps he would like to be remembered particularly for his two sponsored cycle rides some 175 miles each from the West Country back to Witney, the second of which was in his 82nd year.

Michael will be sadly missed and our thoughts are with Betty and their family.

As a final tribute from the dental world, but sadly one that Michael did not live to hear, in January it was announced at a meeting of Branch Council, South Mercia Branch that his name had been forwarded to the BDA HQ as deserving of a Life Membership of the BDA and that this had been ratified. He would have been proud of this rare accolade.

G. Barnes

\section{He had a caring nature and a tireless dedication to the profession he loved.}

affection the support and encouragement they received. In 1968 Norman's expertise in prosthetics prompted him to apply for a parttime teaching post at Dundee Dental School. Though part-time he led an eminent academic career, and his thesis on the aetiology of angular cheilitis gained him his MDS in 1975. In 1978 with Bob Yemm he published the 'Dundee' denture copying technique and in 1981 was honoured with the appointment to honorary senior lecturer.

In 1984 David McGowan set out to pilot a radical, innovative two-year scheme in the West of Scotland to place new graduates in selected training practices for a mentored associateship of one year. Norman was delighted to join in this highly successful venture. He related to all his 'trainees' with rare insight, respecting their professional anxieties and welcoming them as colleagues. Established on a shoestring and driven by vision and determination, this fledgling Scottish vocational training scheme evolved and developed into the national scheme; the rest is history.

After his retirement in 1992 Norman spent many happy years devoted to his family, his church and his life with friends in Aberdeen and Majorca. We send our sympathy to Audrey and his sons Gary and Roderick on the sad loss of Norman, who distinguished our profession with his achievement and generosity of spirit.

M. Steed 